\title{
Do Firm Characteristics and Ownership Structure affect Corporate Philanthropic Contributions in Jordan?
}

Husam Ananzeh, Lecturer, Department of accounting, Irbid National University, IrbidJordan, hussamananzeh@yahoo.com.

Hashem Alshurafat PhD, Assistant Professor, Department of accounting, Hashemite University, Zarqa-Jordan, hashema@ hu.edu.jo, ORCID \#: https://orcid.org/0000-00029514-3826.

Khaled Hussainey, Research Lead, Accounting and Financial Management, Professor of Accounting and Financial Management, Faculty of Business and Law, University of Portsmouth, Portsmouth, PO1 3DE, United Kingdom. E: khaled.hussainey@ port.ac.uk 


\begin{abstract}
We examine the drivers of corporate donations in Jordan. In particular, to examine whether firm-specific characteristics and ownership types affect corporate donations. The analysis is based on a sample of 94 Jordanian listed companies, drawn from the manufacturing and service sectors, over the period 2010-2016. Using OLS regression with year and industry fixed effects; we find that corporate philanthropic contributions are positively associated with company size, age, profitability, media exposure, and governmental ownership. We also find that corporate philanthropic contributions are negatively associated with financial leverage and family ownership. Our study offers a number of important implications for business strategists from the perspective of corporate social performance.
\end{abstract}

Keywords - Corporate philanthropy, corporate social responsibility, Jordan, stakeholder theory 


\section{Introduction}

Companies are strategically working to enhance financial benefits (Mullen, 1997). Adopting corporate philanthropic activities has been argued to be of strategic merit as it can positively enhance corporate gains. Business scholars have recognized corporate philanthropy as a significant phenomenon (Gautier \& Pache, 2015). Recently, many firms have begun engaging in charitable giving activities as a means of enhancing their social and financial benefits (Houqe, van Zijl, Karim, \& St George, 2019). In addition, global organizations, including ADMICAL ${ }^{\mathrm{i}}$, Chief Executives for Corporate Purpose (CECP) ${ }^{\mathrm{ii}}$, and Chronicle of Philanthropy ${ }^{\mathrm{iii}}$ report a growing interest in corporate philanthropy by companies worldwide. The global trend is mainly attributed to the legitimacy shift in adopting corporate philanthropy more recently, where it was once "widely held as an illegitimate practice," it is now considered 'illegitimate' "not to engage in philanthropic activities" (Gautier \& Pache, 2015, p. 343). Here, previous literature has emphasized the need for more investigation into corporate philanthropic practices (Gautier \& Pache, 2015; Saeidi, Sofian, Saeidi, Saeidi, \& Saaeidi, 2015; H. Wang \& Qian, 2011). In particular, there is a growing concern to investigate what determines the philanthropic contributions among corporations of different economic scales, including large firms, small and medium-sized enterprises.

Understanding the determinant factors of corporate philanthropic practice is particularly important to help reinforce companies' accountability around the globe. Despite its importance, however, a complete discussion relates to what determine corporate philanthropic practices is not even exist since there is a lack of research that has addressed 
this research question (Adams \& Hardwick, 1998; Bartkus, Morris, \& Seifert, 2002; Brammer \& Millington, 2004; Collins, 1993; File \& Prince, 1998; Houqe et al., 2019; S. Li, Song, \& Wu, 2015; Majumdar, 1997; Mescon \& Tilson, 1987; Mullen, 1997; Navarro, 1988; Reverte, 2009; Zhang, Rezaee, \& Zhu, 2010). More importantly, there is a significant absence of related evidence in less developed countries. Given this fact and using the country of Jordan as a case selection, this study tends to provide empirical evidence of what factors are likely to affect companies' attitudes against participating in philanthropic practice.

Jordan is a unique context to study the determinants of corporate philanthropic practice as the country has recently witnessed a massive influx of Syrian refugees as a consequence of the Syrian civil war that has begun in 2011. This phase has been characterized by a significant increase in donors' participation and increasing stakeholders' pressure for socially responsible behavior by companies. Therefore, it is worth studying corporate philanthropy and the factors that determine their presence and value in a developing country such as Jordan. This research adopts a stakeholder theory to answer the research question: 'what drives corporate philanthropy engagements in Jordan?'

In the literature, corporate philanthropy is deemed to be an essential and principal type of corporate social responsibilities (Bartkus et al., 2002; Boubaker, Chourou, Himick, \& Saadi, 2017; Brammer \& Millington, 2004; Houqe et al., 2019; S. Li et al., 2015; Reverte, 2009; Zhang et al., 2010). The current study contributes to the literature body on corporate philanthropy in three ways. First, there is a growing literature linking corporate philanthropy to firm performance (X. Li, Li, Wang, Jiao, \& Pang, 2020; Rehman \& Jun, 
2020; Seifert, Morris, \& Bartkus, 2004; H. Wang, Choi, \& Li, 2008; H. Wang \& Qian, 2011). We extend the extant literature by investigating whether the financial performance represented in the profitability and leverage proxies determines companies' charitable giving. Second, in addition to the typical variables such as the firm size and age (Badulescu, Badulescu, Saveanu, \& Hatos, 2018; Çera, Belas, Maroušek, \& Çera, 2020), this study extends the prior studies by understanding the impact of company exposure to media on its ability to provide philanthropic contributions. Third, the literature is inconclusive about the type of corporate ownership that is more engaged with philanthropic practices (Ge \& Micelotta, 2019; Lin, Liu, Huang, \& Chen, 2018; Liu, Wei, Huang, \& Tsai, 2017). This study extends the previous research on the role of corporate ownership structure in determining a company's philanthropic contributions practices.

This article investigates the degree to which firm characteristics and ownership structure affect corporate philanthropic contributions. We find that corporate philanthropic contributions are positively associated with company size, age, profitability, media exposure, and governmental ownership. We also find that corporate philanthropic contributions are negatively associated with financial leverage and family ownership. This study results remain constant using three different regression models, which indicate the validity of the empirical evidence that this study provides. Using the first lag of the dependent variable as a means of control for the endogeneity problem was done in the second model. Simultaneously, the third model used alternative measures of the explanatory variables as an additional way to validate our baseline model's robustness. 
The remainder of this paper is organised as follows. Section 2 provides an overview of the Jordanian context, including a brief discussion of the Syrian crisis. Section 3 reviews the literature. Section 4 discusses the theoretical background of this paper. Section 5 develops the study's hypotheses. Section 6 presents the research methodology. The empirical analysis and the results of this paper are presented in Sections 7, 8, respectively. Section 9 concludes the paper.

\section{Jordanian context:}

Since 2010, Jordan witnessed a massive influx of Arab refugees as a consequence of what is called the Arab Spring. In particular, Syrian refugees have accounted for a large proportion of these flows over the past years. Jordan has been negatively affected by this massive immigration. For example, demand for schools, health facilities, housing, food, energy, and water has increased dramatically (Achilli, 2015). In addition, their access to key public resources has caused various deficiencies in providing services to society. So far, Jordanian government figures show that the cost of hosting the Syrian refugees stands at about 4.2 billion dollars since the beginning of the crisis.

As an attempt to bridge the financial gap, the Jordanian government has sought private sector assistance. Therefore, there are continuous initiatives and structural and political reforms to strengthen the private sectors' role in stimulating economic growth. As a part of this, the concept of Corporate Social Responsibility (CSR) has attracted considerable attention from the government. As a result, the private sector is being asked to participate in government with regards to the core issues of poverty, social issues, and unemployment in Jordan (Sharabati, 2018). 
Companies' perception of CSR is different between the West and the East (Pratten \& Abdulhamid Mashat, 2009; Schmidt \& Cracau, 2017). Moreover, the perception of CSR is not homogeneous among Jordanian companies (Abdelrahim, 2014). For years, due to culture, religious beliefs, and family values, the predominant perceptions of CSR have been that it simply means philanthropic donations (Al-daaya, 2017; Tilt, 2016). Therefore, this study seeks to investigate the philanthropic donations of the Jordanian listed companies during the period 2010-2016, and how these contributions can be determined through various factors at the corporate level.

The decision to choose the country (Jordan) as a context for this research has been made for many reasons. First, the intensive need of the Jordanian government to be helped financially in dealing with hosting and serving a large number of refugees. Thus, corporate philanthropy could be an essential strategic tool for the private sector in Jordan. Second, Jordan is classified in the 'Upper middle income' level by the World Bank. Thus, corporate philanthropy and charitable giving are projected to attract more loyal stakeholders for the corporation as the corporate philanthropy might reach a broader segment of stakeholders. Third, due to cultural beliefs, in Jordan, corporate philanthropy is deemed the most prevalent form of CSR (Al-daaya, 2017; Tilt, 2016). This emphasizes the importance of corporate philanthropy for Jordanian firms, at least as a marketing strategy. All the abovementioned reasons made Jordan a proper context to learn what we do not learn from other contexts. 


\section{Literature review}

Instead of being an extra strategy available to corporate managers, philanthropy is considered a necessity for corporate success in financial performance and market competition (Brammer \& Millington, 2006; Saiia, 2001; Seifert, Morris, \& Bartkus, 2003). Bruch (2005, p. 49) has stated that "effective philanthropy must be run no less

professionally than the core business." Philanthropy is used as a tool to establish and develop relationships with stakeholder groups, which, in turn, might positively influence corporate financial performance (Abdulla AlNaimi, Hossain, \& Ahmed Momin, 2012; Brammer \& Millington, 2006; Godfrey, 2005; Hillman \& Keim, 2001).

Among various CSR tools that companies regularly use, the value relevance of corporate philanthropy to the companies has been widely examined by many researchers (Collins, 1993; File \& Prince, 1998; Henderson \& Malani, 2009; Mescon \& Tilson, 1987; Orlitzky, Schmidt, \& Rynes, 2003; Patten, 2008; Seifert et al., 2004; H. Wang et al., 2008; H. Wang \& Qian, 2011; Williams, 2003). H. Wang and Qian (2011) have indicated that corporate philanthropy is increasingly anticipated to affect firm financial performance positively and is foreseen to provide firms with socio-political legitimacy. Others have argued that the social capital and social value the company possesses are a direct reflection of the company's philanthropy (Houqe et al., 2019). For many managers, company philanthropy is not only to give to a charity; it is to build the future of the society in which they operate (Brammer \& Millington, 2006).

Corporate donations have been recognized as the oldest form of social responsibility behavior adopted by corporations. In recent years, companies have turned away from this 
traditional way of giving toward other social responsibility behaviors such as good practice towards the environment, human resources, and research and development (Karyawati, Angesty, \& Joshi, 2017). However, it has been evident that corporate philanthropy is the strategy most linked to the bottom-line of firms' income statements (Mescon and Tilson, 1987). Moreover, among developing countries, CSR is mostly practiced in the form of philanthropic donations, which is due to culture, religious beliefs, and family values (Aldaaya, 2017; Tilt, 2016).

Godfrey (2005) has asserted that corporate philanthropy and charitable giving generate helpful, ethical capital among shareholders, which gives shareholders insurance-like protection that contributes to shareholder wealth. Henderson and Malani (2009) have deliberated on the role of different organization types in philanthropy practices. They assert that for-profit organizations can most benefit from charitable giving if they have a competitive advantage over non-profit organizations and government. Henderson and Malani (2009) have suggested that corporate philanthropy can be used as a strategy to benefit different groups of stakeholders and firms. Moreover, they have suggested that the government should deal equally with taxation policies with non-profit organizations and firms that engage in charitable giving.

To sum up, it can be seen from the reviewed literature that the prior studies mainly focused on the value relevance of the philanthropic contributions to the firms' financial performance (Brown, Helland, \& Smith, 2006; Chun, 2019; Jia, Xiang, \& Zhang, 2019). Most of the studies are conducted in developed countries' settings, while few empirical studies have covered the developing countries' settings (Boubaker, Nguyen, \& Nguyen, 2012; Boubaker 
\& Nguyen, 2012, 2014). This study attempts to address the knowledge gap found in the literature and to extend the scope of the previous literature by cover the factors that determine the philanthropic contributions of firms in a developing country context.

Prior research has offered recommendations to advance the philanthropic contribution, strategies, and culture among the corporations in the developing countries context (Adams \& Hardwick, 1998; Bartkus et al., 2002; Brammer \& Millington, 2004; Collins, 1993; File \& Prince, 1998; Houqe et al., 2019; S. Li et al., 2015; Majumdar, 1997; Mescon \& Tilson, 1987; Mullen, 1997; Navarro, 1988; Reverte, 2009; Zhang et al., 2010). The literature review highlights the importance of CSR and philanthropy to the companies (Abebe \& Cha, 2018; Bruch, 2005). In addition, it is evident that there are multiple barriers to philanthropic practices. Overall, prior research suggests that obtaining a collective understanding of what hinders or supports corporate philanthropic contributions is essential when developing a philanthropic strategy (Pratten \& Abdulhamid Mashat, 2009; Schmidt \& Cracau, 2017). Thus, it is the time for this study to focus principally on identifying the key factors that are probably influencing the corporate philanthropic contributions. This study extends the previous studies by understanding the firm characteristics and ownership structure in determining corporate philanthropic contributions.

\section{Theoretical framework}

The body of literature in the field of CSR and corporate governance has contributed to a wide range of empirical evidence which underpins this research with regards to developing the research hypotheses. The fabric of empirical evidence that has been found in the prior literature has been explained using various theoretical lenses, including agency cost (see 
for example: Brown et al., 2006; Houqe et al., 2019; Masulis \& Reza, 2014; Seifert et al., 2003; J. Wang \& Coffey, 1992), stakeholder theory (see for example: Brammer \& Millington, 2004, 2006; Hillman \& Keim, 2001), the theory of planned behavior (Dennis, Buchholtz, \& Butts, 2009) and social identity theory (see for example: Clevenger, MacGregor, \& Ryan, 2019). The empirical model elaborated here will be discussed using a stakeholder theory lens (Brammer \& Millington, 2004; Carroll, 1979; Jensen, 2002; Roberts, 1992).

The "stakeholder theory" term was first used by Ansoff (1965), who defined the objectives of a firm. The term stakeholder has been defined by Freeman (1984) as "any group or individual who can affect or is affected by the achievement of the firm's objectives." The main objective of a firm is to accomplish a balance between the conflicting demands of various stakeholders in the firm. As part of his work on corporate planning and business policy models, as well as CSR, Freeman (1984) has developed the concept of stakeholders and matched it to corporate governance and social responsibility issues. A firm's stakeholders might include suppliers, customers, employees, creditors, governmental bodies, and public interest groups. These categories of stakeholders are collaborative and not adversarial.

Stakeholder theory has been widely used in analytical and empirical analyses of companies and settings in which they operate (Brammer \& Millington 2006). Freeman (1984) has deliberated the underlying biases of stakeholders as influences on corporate decisions. As corporate management's primary role is to meet the stakeholders' demands, in conjunction with the firm's strategic objectives, the CSR idea includes external influences on the firm 
that may negatively affect its stakeholders' interests. CSR permits a firm to adapt actions in order to address the social requirements of non-traditional power groups. Roberts (1992) has suggested that stakeholder theory offers a suitable explanation for studies of CSR activities.

\section{Hypotheses development}

The empirical model elaborated here hypothesizes that corporate donations are determined by firm size, firm profitability, ownership structure, firm age, leverage, and media exposure. Each of these will be discussed in turn using the stakeholder theory lens (Brammer \& Millington, 2004; Carroll, 1979; Jensen, 2002; Roberts, 1992).

\section{Firm size}

Literature that discusses evidence on firm size has suggested an increasing social burden on large organizations (Brammer \& Millington, 2006). Brammer and Millington (2006) have found a positive relationship between firm size and philanthropy; however, this sizephilanthropy relationship significantly varied between different industries. Firm size represents a variety of organizational characteristics such as economies of scale in production and competitive advantage (Adams \& Hardwick, 1998; Karyawati et al., 2017; Pichler, Cordazzo, \& Rossi, 2018). The positive relationship between firm size and CSR in general and corporate giving, in particular, can be attributed to both the availability of a firm's resources and maturity in investment decisions that large firms usually have (Habbash, Hussainey, \& Ibrahim, 2016; Karyawati et al., 2017). Furthermore, by adopting a sample of 100 UK listed companies, Adams and Hardwick (1998) have referred to a positive relationship between firm size and corporate philanthropy levels. 
Hypothesis 1: The level of corporate philanthropic expenditure is positively associated with firm size.

\section{Firm age}

Firm age may impact a firm's financial performance because firm maturity may be used as a proxy for a firm's reputation (Erhemjamts, Li, \& Venkateswaran, 2013), and the level of competitiveness may be linked to a firm's experience (H. Wang et al., 2008). Mature companies are believed to be better-established than younger firms. Therefore, firm maturity is likely to have an impact on a company's socially responsible activities. More mature companies may carry out more CSR activities, including philanthropic contributions, in order to maintain/improve their reputation (Erhemjamts et al., 2013). On the other hand, younger companies may seek to differentiate themselves and thereby gain a competitive advantage by committing to more CSR activities. However, there is no evidence of how firm age may impact corporate philanthropic contributions (Lee, Faff, \& Langfield-Smith, 2009; Orlitzky, Siegel, \& Waldman, 2011; Saeidi et al., 2015; Weber, 2008). Still, this paper tends to accept the argument that mature companies are likely to be more inclined to show concern with society's needs. Thus, mature firms are expected to participate in philanthropic practices. Based on the reviewed literature, the following second hypothesis was drawn.

Hypothesis 2: The level of corporate philanthropic expenditure is positively associated with firm age. 


\section{Firm profitability}

Philanthropic strategies are predicted to draw social attention to the company, and therefore indirectly enhance a company's financial performance (Brammer \& Millington, 2005). Seifert et al. (2003) have indicated a positive relationship between corporate philanthropy and financial performance. Adams and Hardwick (1998) have found a positive relation between firm profitability and the decision to contribute funds to charities. H. Wang et al. (2008) have argued that corporate philanthropy correlated with corporate financial performance in an inverse U-shape relationship. Specifically, they have shown a positive relationship between corporate philanthropy and corporate financial performance up to a particular limit when corporate philanthropy highly increases, which then reflects agency costs and direct cost. While agency theory predicts an association between available resources and corporate giving (Masulis \& Reza, 2014; Seifert et al., 2003), stakeholder theory predicts more corporate giving when firms have more available financial resources (Gautier \& Pache, 2015; Godfrey, 2005).

In addition to the social benefits, Barnett (2019) has noted that firms could profit from CSR and charitable giving activities. Consequently, it can be inferred that profitable firms have the discretionary funds to contribute to philanthropic and other charitable programs, while firms with low profits are expected to limit managerial concern over social responsibility costs. Indeed, using a sample of 703 companies listed on the Chinese stock market, Zhang et al. (2010) have investigated how the profitability of these firms being affected by the amount of their philanthropic response to the 2008 Sichuan earthquake. They have revealed that profitability was positively associated with corporate philanthropy decisions and 
amounts. Therefore, based on the literature discussed, the relationship between philanthropic activity and firm profitability can be captured in the following hypothesis.

Hypothesis 3: The level of corporate philanthropic expenditure is positively associated with firm profitability.

\section{Leverage}

In the stakeholder theory literature, companies are anticipated to satisfy and meet the claims of all stakeholders, including the local community and governmental agencies, rather than focusing on satisfying contractual claims of stakeholders such as debt-holders to receive a satisfactory return on their investment (Brammer \& Millington, 2004, 2006; Masulis \& Reza, 2014; Roberts, 1992). In addition to the high risk of bankruptcy, companies with high leverage suffer from different contracting challenges, which may include investment restrictions, many audits of a company's financial data, sinking-fund requirements, and liquidity tests. These costs have particular impacts on companies' expenditures and beyond, for example, high corporate leverage leads to job losses.

It has been evident in the literature that companies with high social responsibility may be associated with a low percentage of debt to assets (Brammer \& Millington, 2005, 2006; Masulis \& Reza, 2014; H. Wang et al., 2008; H. Wang \& Qian, 2011). Put another way, companies with a low percentage of debt to assets (low leverage) often show an association with low contracting costs. Hence, corporate owners and managers would be able to engage with more philanthropic practices that meet some external stakeholders' claims. Therefore, the following hypothesis was formulated. 
Hypothesis 4: Corporate philanthropy is negatively correlated with corporate leverage.

\section{Media exposure}

Companies tend to draw their surrounding community's attention through advertising practices (Patten, 2002); media exposure plays a significant role in doing so. Consistently, firms with higher media exposure show more significant CSR activity. Firms expose themselves to media as it is the most effective avenue to share CSR information and philanthropic practices (Simon, 1992). Brown et al. (2006) have shown that companies with high advertisement expenses give more to charity. Consequently, Reverte (2009) has studied the association between media exposure and CSR disclosure ratings by studying the largest 35 Spanish firms listed on the Madrid Stock Exchange and included in the IBEX35 index. Reverte (2009) has concluded that companies that donate more generously are associated with more media exposure. H. Wang and Qian (2011) have revealed that a more effective philanthropic practice in terms of financial performance is more evident within firms with greater public visibility and for firms with better past financial performance because generosity by these companies increases more positive stakeholder gains. In light of the previous literature, the following hypothesis has been structured.

Hypothesis 5: The level of corporate philanthropic expenditure is positively associated with media attention.

\section{Ownership structure}

According to Haley (1991), managers benefit from making charitable decisions related to their local communities; these benefits could increase their prestige, reputational capital, and social connections. This argument is contradicted by Navarro (1988), who has 
suggested that managers' awareness of the social responsibility of their firms was a crucial factor in guiding their philanthropic decisions. However, a firm's philanthropic practices could be at the expense of maximizing shareholders' wealth (Adams \& Hardwick, 1998; Owusu \& Weir, 2018). According to Zhang et al. (2010), firm ownership type is an important determinant of corporate philanthropic practices. In firms with less concentrated ownership structures, managers are expected to have significant discretion over operational decisions compared with managers in companies with high concentrated ownership structures (Adams \& Hardwick, 1998; Grossman \& Hart, 1980; S. Li et al., 2015). Therefore, corporate donations are expected to be high whenever a firm has a less concentrated ownership structure (Adams \& Hardwick, 1998; Grossman \& Hart, 1980).

In addition, state-ownership and family ownership are considered important ownership factors that might influence CSR activities, including corporate donation practices. According to Abdullah, Mohamed, and Mokhtar (2011), state-owned companies are under pressure to respond to government pressure regarding CSR requirements. Thus, the more shares owned by the government, the more pressure is exerted on management to meet the government's expectations regarding such activities (Ibrahim, Habbash, \& Hussainey, 2019; Roberts, 1992); this might have a positive impact on corporate donation practice. On the other hand, family-owned companies might have less motivation to be responsive to CSR as they are perceived to be more inclined to be profit-making and less inclined to engage with public accountability (Chau \& Gray, 2010). In light of the previous literature, the following hypotheses were designed: 
Hypothesis 6: Corporate philanthropy is positively correlated with a low concentrated ownership structure.

Hypothesis 7: Family-owned companies have less incentive to make more charitable contributions.

Hypothesis 8: Government-owned companies have more incentive to make more charitable contributions.

\section{Method}

\section{Study sample}

This study aimed to examine the determinant factors of corporate donations in Jordan. A quantitative approach was adopted for this research, and information about corporate philanthropic donations was manually collected based on a sample of 94 Jordanian listed companies over the period 2010-2016. 2010 was chosen as the starting year for the period under investigation since the outbreak of the Arab Spring was witnessed early in the same year. From then on, Jordan has experienced a constant decrease in the country's GDP and damage to several sectors such as trade, industry, construction, and tourism. We believe that the Arab Spring, jointly with the Syrian crisis, has led companies to increase their philanthropic practices.

The sample included companies that operate in the manufacturing and service sectors. This study has deleted the financial sector sample as the country's economy is mainly upheld by the service and industrial sectors. Jordanian companies were required by the Securities Law of 2002 to disclose their donations and grants during the fiscal year (Haddad, Sbeiti, \& 
Qasim, 2017). As such, the annual reports of the companies have been used as the source of study data in terms of corporate donations.

\section{Specification of study variables}

The dependent variable was corporate donations, as revealed in the company's annual reports. For analysis purposes, the ratios of corporate donations to company total assets were used. According to Brammer and Millington (2004), adopting such scaled values, rather than the absolute number of corporate donations, has two main advantages. First, it corrects for the heteroscedasticity problem. Second, it helps to control the intra-firm size differences. Thus, concerns about whether large firms give more to charity can be avoided.

Conversely, independent variables were measured following previous studies. The first determinant factor is the firm size, which was calculated as the natural logarithm of the number of employees, and this measurement is consistent with (Brammer \& Millington, 2006). The second determinant factor is firm age, which is measured in a manner consistent with H. Wang and Qian (2011, p. 1168, 1168) study: "firm age was measured as the number of years since a firm's initial public offering." The third determinant factor was the firm profitability ratio of return on assets (ROA), consistent with (Abdullatif, Alhadab, \& Mansour, 2019).

The fourth determinant factor was the financial leverage ratio, which is measured as total debt divided by total assets (Abdullatif et al., 2019; Zhang et al., 2010). Media exposure was the fifth determinant factor and was measured as the average number of CSR related articles published by local newspapers (Patten, 2002, 2008). Ownership structure was the sixth determinant factor and was measured using the ratio of shares held by the substantial 
shareholders (above $5 \%$ ) as described by Abdullatif et al. (2019). The penultimate determinant factor was family ownership, which is represented by the ratio of shares held by family members and their relatives in line with the study by Campopiano, De Massis, and Chirico (2014). The last determinant factor was governmental ownership, which is represented by the ratio of shares held by government institutions (Zhang et al., 2010). Table I shows the measurement of the study variables as well as the data source.

\section{[INSERT TABLE I ABOUT HERE]}

Research model

This study examined the association between the explanatory variables and corporate donations using Ordinary Least Square (OLS) regression, which incorporates the following explanatory variables:

\section{Model (1)}

$$
\begin{aligned}
& \text { DONTS }_{i t}=\beta_{0}+\beta_{1} \text { SIZE }_{i t}+\beta_{2} \text { AGE }_{i t}+\beta_{3} \text { PROF }_{i t}+\beta_{4} \text { LEVER }_{i t}+\beta_{5} \text { MEDIA }_{i t+}+ \\
& \beta_{6} \text { OWNC }_{i t}+\beta_{7} \text { FOWN }_{i t}+\beta_{8} \text { GOWN }_{i t}+\text { Sector }_{i}+\text { Year }_{t}+\varepsilon_{i t}
\end{aligned}
$$

Where:

(DONTS) is the ratio of corporate donations to company total assets, (SIZE) is the company size, (AGE) is the company age, (PROF) is the company profitability, (LEVER) is the company financial leverage, (MEDIA) is to what extent the company has exposed to social and environmental issues, $(O W N C)$ is the ownership concentration, (GOWN) is the 
government ownership, (FOWN) is the family ownership, (Year) is the year dummies;

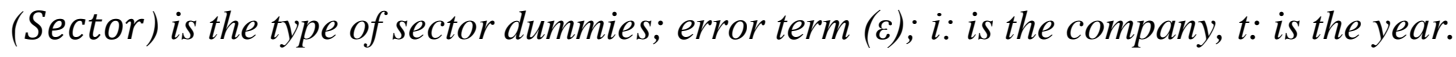

\section{Empirical analysis}

This study used panel data to test the hypotheses; Table II presents a descriptive analysis for the study variables, namely, means, standard deviations, the minimum, and the maximum. A wide range of variation is evident in the study sample. Descriptive results show that the average value of scaled donations was $53 \%$, with a wide range of $0 \%$ to $9.985 \%$. Thus, there was a considerable variation in the study sample in terms of donation behavior. On the other hand, regarding company characteristics, the mean values of the companies' size (in logarithm), age (in logarithm), profitability, and leverage were 10.286, $2.953,2.013, .325$, and 2.956 , respectively.

Moreover, the mean value of the media coverage was .583, with a minimum value of 0 and a maximum value of 15 . Across the 94 Jordanian companies, the ownership concentration had a mean value of $60 \%$, revealing that the ownership in Jordan is noticeably concentrated. Furthermore, the mean value of government ownership was $6 \%$. These results are in line with those of (Al-Akra, Eddie, \& Ali, 2010), who asserted that the participation of the Jordanian government in public shareholding companies amounted to about $15 \%$ and decreased to $6 \%$ after the privatization process, which started in 1997. Finally, the mean value of family ownership was about $19 \%$.

[INSERT TABLE II ABOUT HERE] 


\section{Correlation analysis}

According to Wooldridge (2013), multicollinearity is a problem when a high correlation between two or more independent variables can be observed. Table III presents the correlation matrix between this study's variables. The correlation analyses act as a guide for the multicollinearity presence between the continuous independent variables. According to Gujarati (2003), a correlation coefficient of around eight or higher can indicate a presence of serious multicollinearity. However, results indicate that multicollinearity among the independent variable was not a problem in this study.

\section{[INSERT TABLE III ABOUT HERE]}

\section{Results}

The study's hypotheses were tested using the OLS model. The explanatory variables regressed on the corporate donations using year and industry fixed effect. The robust standard error method was adopted to correct for heteroskedasticity (Huber, 1967; White, 1982). Table IV shows that DONTS is positively associated with SIZE, AGE, PROF, MEDIA, and GOWN, while it is negatively associated with LEVER and FOWN. However, DONTS is not associated with OWNC.

\section{[INSERT TABLE IV ABOUT HERE]}

In this study, larger companies were found to make higher levels of philanthropic contributions. Therefore, SIZE was found to be positively correlated with DONTS. Thus, H1 was supported at level $(\mathrm{p}<0.01)$ of significance. This finding supports the views of Adams and Hardwick (1998) and Brammer and Millington (2006), who have pointed to 
the existence of a positive relationship between corporate size and the level of corporate donations. Moreover, it supports the argument that big sized companies have the ability and sources to engage more in charitable giving than small-sized companies. AGE was also found to be positively correlated with DONTS. Thus, $\mathrm{H} 2$ was supported at a level ( $\mathrm{p}$ $<0.05)$ of significance.

This indicates that the more mature Jordanian firms are more likely to engage in more philanthropic activities. Compared to the newly established firms, mature firms may tend to increase the level of their philanthropic activities in order to enhance their reputation and/or to gain a better competitive advantage. Our result is in line with Erhemjamts et al., 2013, who have referred to the existence of a positive relationship between company age and the extent to which firms engage in CSR-related activities.

Moreover, PROF was found to be positively correlated with DONTS. Thus, H3 was supported at a level $(\mathrm{p}<0.05)$ of significance. This finding is consistent with earlier works by Seifert et al. (2003) and Adams and Hardwick (1998), who have found a positive relationship between corporate profitability and corporate donations. However, this finding is partially consistent with Wang et al. (2008), in which an inverse U-shape relationship between corporate profitability and corporate donation is confirmed. Our finding supports the view that high-profit companies tend to donate more and financial resources are a key driver for charitable giving (Seifert et al. 2003). Besides, this finding supports the argument 
that firms engage more in corporate giving when they have more available financial resources (Godfrey 2005; Gautier \& Pache 2015).

On the other hand, LEVER was found to be negatively correlated with DONTS. Thus, H4 was supported at level $(\mathrm{p}<0.01)$ of significance. This means that in Jordan, a reduction in the financial leverage is likely to be followed by an increase in the level of corporate donation, or vice versa. This result is in line with findings by Brammer \& Millington (2004) and Adams and Hardwick (1998), while on the other hand, it contradicts findings by Erhemjamts et al., 2013, in which an insignificant relationship between corporate philanthropy and corporate financial leverage is evidenced. The study finding supports the view that leveraged firms tend to meet creditors' liabilities rather than giving to charities. Furthermore, this result indicates that creditors monitor the leveraged firms' financial distributions; therefore, leveraged firms cannot contribute to philanthropic practices (Brammer \& Millington, 2005, 2006; Masulis \& Reza, 2014; H. Wang et al., 2008).

Consistent with Patten (2002) and Reverte (2009), MEDIA was found to be positively correlated with DONTS. Thus, H5 was supported at a level $(\mathrm{p}<0.05)$ of significance. To what extent a company is exposed to the media has been used as a proxy of that company's visibility (Brammer \& Millington, 2006). Hence, more media coverage invites further public attention and scrutiny (Brown et al., 2006; Patten, 2002; Reverte, 2009; Saeidi et al., 2015; Simon, 1992). Furthermore, this finding supports the argument that firms use donations and philanthropic practices as a marketing and advertising strategy.

By contrast, OWNE was not correlated to corporate donations, and H6 was therefore rejected. Similar insignificant relationships were evidenced by Adams and Hardwick 
(1998) and Li et al. (2015). On the other hand, FOWN was found to be negatively correlated with DONTS. Thus, H7 was supported at level $(\mathrm{p}<0.01)$ of significance. This means that Jordanian family-owned companies are less likely to engage in philanthropic practices. Our finding is in line with Abdullah et al. (2011), who have found a negative and significant relationship between family ownership the level of CSR-related activities. This finding supports the view that family-owned companies have less incentive to make charitable contributions. Furthermore, GOWN was found to be positively correlated with DONTS. Thus, H8 was supported at level $(\mathrm{p}<0.01)$ of significance. Our result contradicts findings by Zhang et al. (2010) and Li et al. (2015), who have found government ownership to negatively affect corporate donations in China. Our finding supports the view that stateowned companies have more incentive to make charitable contributions.

\section{Robustness test}

For the robustness test, two alternative regressions were estimated. Model 2 was first run using the first lag of the dependent variable as a means of control for the endogeneity problem (see Table IV). While the results of Model 2 have remained consistent with those of Model 1, MEDIA has become insignificantly associated with the level of corporate donations. In addition, using alternative measures of the explanatory variables can be considered as an additional way in which the robustness of our baseline model can be validated. Model 3 was carried out using the natural logarithm of company assets as an alternative proxy of company size (SIZE), the natural logarithm of the number of years since establishment was used as an alternative proxy of the company age (AGE), and the ratio of the return on equity was used as an alternative proxy of company profitability (PROF). In addition, as an alternative measure of government ownership, a dummy 
variable that equalled (1) if the company has shares owned by the government was used. Before re-running the regression, all continuous variables were truncated at the top and the bottom 1\%. The results of Model 3 were in line with those obtained from Model 1, which indicates the validity of our baseline model.

\section{Discussion and conclusion}

This paper examined the determinant factors of the Jordanian corporate donations after the Syrian crisis. By using the stakeholder theory lens and quantitative methods, some interesting results were obtained. Using a sample of 94 listed Jordanian companies, covering the period of 2010 to 2016 , the results of this study have shown that corporate size, age, profitability, media attention, and governmental ownership were positively associated with corporate donations. On the other hand, leverage and family ownership were negatively associated with the occurrence of corporate donations. Surprisingly, this paper has found that ownership concentration was not correlated with a corporate donation. The revealed evidence suggests that large-sized and mature companies with a higher level of profitability and exposure to the public via media, and those controlled by the government, exhibit higher charitable giving levels. On the other hand, family-owned companies with a higher level of debt exhibit a lower level of charitable giving.

The results from this research provide some support for different arguments by prior researchers and refute some other arguments. First, the availability of resources for companies plays a significant role in enhancing charitable giving (Brammer and Millington 2006). Large-sized companies that have financial resources have shown more tendencies to engage in philanthropic practices. This finding is consistent with the argument that profit 
and size are significant determinants of corporate philanthropy (Adams \& Hardwick, 1998). Second, this paper has found that mature companies are less likely to engage in philanthropic activities, which contradicts the idea that more mature companies may carry out more philanthropic contributions in order to maintain/improve their reputation (Erhemjamts et al., 2013). Third, leveraged firms show fewer tendencies to engage in philanthropic practices. This result is consistent with the argument that powerful monitoring by creditors leads leveraged firms to give a smaller amount of money to charities (Roberts 1992; Brammer \& Millington 2004, 2006; Masulis \& Reza 2014).

Fourth, as this paper has found that media exposure is positively correlated with a firm's donation, this finding is consistent with the argument that those firms that market themselves more intensively also give more to charity (Simon, 1992). Fifth, this paper has found that government-entities are likely to engage in more corporate donations. Government-owned companies are under pressure to respond to government pressure with regards to CSR requirements (Abdullah et al., 2011). Regarding family ownership, this study's finding is consistent with the argument that family-owned companies are less likely to contribute to charitable practices. These companies might be more inclined to focus on profit-making rather than public accountability (Chau \& Gray, 2010). Finally, in this research, this paper was unable to find a relationship between ownership concentration and corporate donations.

This study contributes to the literature by examining how companies in Jordan are encouraged to make charitable contributions. There is a significant absence of studies that have questioned the determinant of corporate donations among the developing countries. 
By empirically investigating the determinants of corporate donations in Jordan, this study will likely extend the early studies' scope in this research area. The empirical evidence has demonstrated that corporate philanthropic contributions can be explained by factors related to a firm's characteristics. These findings also contribute in general to corporate philanthropy literature by shedding more light on a set of determinant factors that have not all been sufficiently examined in previous research (e.g., media exposure and ownership types).

Furthermore, the present study's findings are particularly relevant and offer several policy/practical implications for several interested parties in Jordan, such as policymakers, investors, managers, and academics. The study findings draw attention to the need to initiate new measures that would drive the Jordanian companies to genuinely adhere to more philanthropic practices. For example, the Jordan Securities Commission ${ }^{\text {iv }}$, in its duties as a regulator and supervisor of Jordanian public listed companies, may regulate philanthropic policies to increase awareness of publicly listed companies towards charitable giving, i.e., its importance and its value relevant to the firm's value. In addition, as the Income and Sales Tax Department ${ }^{\mathrm{v}}$ offsets $25 \%$ of a firm's donation from its taxable income, this paper encourages the Income and Sales Tax Department to update its policy of corporate donation by offsetting a higher proportion of corporate donations from a firm's taxable income.

More importantly, this study is likely to offer crucial implications for regulatory bodies in Jordan. In determining reasons for non-participating in philanthropic activities, this study has revealed that the low level of philanthropic donation relates to the increase in family 
dominance in the companies. Considering these findings, regulatory bodies ought to resort to a more rigorous approach in order to enhance the level of corporate philanthropy throughout the country. One option, for example, is to pinpoint some measures that discourage family dominance in listed companies, such as initiating an education strategy that targets a wide range of stakeholder groups, mainly shareholders, investors, customers, and the general public. The initiation of such a strategy is likely to positively influence the degree to which these parties can realize the importance of corporate philanthropy.

Furthermore, this study provides an instructive and new insight into the positive relationship between media exposure and the level of corporate philanthropic practices. Given the lack of research demonstrating such a relationship, particularly among the Arab region, the importance of considering such factors is to be highlighted when examining the determinants of corporate philanthropic practices in these countries. These results, therefore, opens new horizons for academics to make further investigations in this area of research, particularly among the developing nations.

Each research design has its challenges and limitations. This study represents a relatively small sample, i.e., only companies listed on the Amman Stock Exchange. Therefore, the generalizations of results may be limited to listed companies and cannot be assumed to be transferable to unlisted companies (Ibrahim \& Hanefah 2016). Research on corporate philanthropy is limited in quantity in developing countries' contexts. Therefore, replication of this study is needed in other developing countries' contexts to examine what determines corporate philanthropic contribution adequately. Due to unexpected results related to the 
correlation between firm age and ownership types and corporate donations, more detailed studies of these variables are encouraged. 


\section{References}

Abdelrahim, K. E. (2014). Role of Corporate Social Responsibility in alleviating poverty in Jordan: an exploratory study. International Journal of Business and Social Research, 4(3), 87-105.

Abdulla AlNaimi, H., Hossain, M., \& Ahmed Momin, M. (2012). Corporate social responsibility reporting in Qatar: a descriptive analysis. Social Responsibility Journal, 8(4), 511-526.

Abdullah, S. N., Mohamed, N. R., \& Mokhtar, M. Z. (2011). Board independence, ownership and CSR of Malaysian large firms. Corporate Ownership \& Control, 8 (3 Sprg), 417-431.

Abdullatif, M., Alhadab, M., \& Mansour, I. (2019). Determinants of Related Party Transactions in Jordan: Financial and Governance Factors. Australasian Accounting, Business and Finance Journal, 13(1), 44-75.

Abebe, M., \& Cha, W. (2018). The effect of firm strategic orientation on corporate philanthropic engagement. Management Decision, 56 (3), 515-533.

Achilli, L. (2015). Syrian refugees in Jordan: a reality check. In M. P. Centre (Ed.).

Adams, M., \& Hardwick, P. (1998). An analysis of corporate donations: United Kingdom evidence. Journal of Management studies, 35(5), 641-654.

Al-daaya, Y. (2017). Corporate Social Responsibility Scenario in Jordan: Transformation Context. 2(3). Retrieved from DOI: 10.21791/IJEMS.2017.3.1.

Al-Akra, M., Eddie, I. A., \& Ali, M. J. (2010). The association between privatisation and voluntary disclosure: evidence from Jordan. Accounting and business research, 40(1), 55-74.

Ansoff, I. (1965). Corporate Strategy McGraw Hill. New York.

Badulescu, A., Badulescu, D., Saveanu, T., \& Hatos, R. (2018). The relationship between firm size and age, and its social responsibility actions-Focus on a developing country (Romania). Sustainability, 10(3), 805.

Barnett, M. L. (2019). The business case for corporate social responsibility: A critique and an indirect path forward. Business \& Society, 58(1), 167-190.

Bartkus, B. R., Morris, S. A., \& Seifert, B. (2002). Governance and corporate philanthropy: restraining Robin Hood? Business \& Society, 41(3), 319-344.

Boubaker, S., Chourou, L., Himick, D., \& Saadi, S. (2017). It's about time! The influence of institutional investment horizon on corporate social responsibility. Thunderbird International Business Review, 59(5), 571-594.

Boubaker, S., Nguyen, B. D., \& Nguyen, D. K. (2012). Corporate governance: recent developments and new trends: Springer Science \& Business Media.

Boubaker, S., \& Nguyen, D. K. (2012). Board directors and corporate social responsibility: Palgrave Macmillan. 
Boubaker, S., \& Nguyen, D. K. (2014). Corporate governance and corporate social responsibility: Emerging markets focus: World Scientific.

Brammer, S., \& Millington, A. (2004). The development of corporate charitable contributions in the UK: A stakeholder analysis. Journal of Management studies, 41(8), 1411-1434.

Brammer, S., \& Millington, A. (2005). Corporate reputation and philanthropy: An empirical analysis. Journal of Business Ethics, 61(1), 29-44.

Brammer, S., \& Millington, A. (2006). Firm size, organizational visibility and corporate philanthropy: An empirical analysis. Business Ethics: A European Review, 15(1), 6-18.

Brown, W. O., Helland, E., \& Smith, J. K. (2006). Corporate philanthropic practices. Journal of corporate finance, 12(5), 855-877.

Bruch, F. W. H. (2005). The keys to rethinking corporate philanthropy. MIT Sloan management review, 47(1), 49.

Campopiano, G., De Massis, A., \& Chirico, F. (2014). Firm philanthropy in small-and medium-sized family firms: The effects of family involvement in ownership and management. Family Business Review, 27(3), 244-258.

Carroll, A. B. (1979). A three-dimensional conceptual model of corporate performance. Academy of management review, 4(4), 497-505.

Çera, G., Belas, J., Maroušek, J., \& Çera, E. (2020). Do size and age of small and medium-sized enterprises matter in corporate social responsibility? Economics and Sociology, 13(2), 86-99.

Chau, G., \& Gray, S. J. (2010). Family ownership, board independence and voluntary disclosure: Evidence from Hong Kong. Journal of International Accounting, Auditing and Taxation, 19(2), 93-109.

doi:https://doi.org/10.1016/j.intaccaudtax.2010.07.002

Chun, H. M. (2019). Does corporate philanthropic giving reduce analyst earnings dispersion? Evidence from Korea. Corporate Social Responsibility and Environmental Management, 26(4), 956-964.

Clevenger, M. R., MacGregor, C. J., \& Ryan, C. (2019). Corporate Philanthropy. In Business and Corporation Engagement with Higher Education (pp. 51-66): Emerald Publishing Limited.

Collins, M. (1993). Global corporate philanthropy-marketing beyond the call of duty? European Journal of Marketing, 27(2), 46-58.

Dennis, B. S., Buchholtz, A. K., \& Butts, M. M. (2009). The nature of giving: A theory of planned behavior examination of corporate philanthropy. Business \& Society, 48(3), 360-384.

Erhemjamts, O., Li, Q., \& Venkateswaran, A. (2013). Corporate social responsibility and its impact on firms' investment policy, organizational structure, and performance. Journal of Business Ethics, 118(2), 395-412. 
File, K. M., \& Prince, R. A. (1998). Cause related marketing and corporate philanthropy in the privately held enterprise. Journal of Business Ethics, 17(14), 1529-1539.

Freeman, R. E. (1984). Strategic management: A stakeholder approach: Cambridge university press.

Gautier, A., \& Pache, A.-C. (2015). Research on corporate philanthropy: A review and assessment. Journal of Business Ethics, 126(3), 343-369.

Ge, J., \& Micelotta, E. (2019). When does the family matter? Institutional pressures and corporate philanthropy in China. Organization Studies, 40(6), 833-857.

Godfrey, P. C. (2005). The relationship between corporate philanthropy and shareholder wealth: A risk management perspective. Academy of management review, 30(4), 777-798.

Grossman, S. J., \& Hart, O. D. (1980). Takeover bids, the free-rider problem, and the theory of the corporation. The Bell Journal of Economics, 42-64.

Gujarati, D. N. (2003). Basic econometrics ((4th, international ed.) ed.): Boston,[Mass.].

Habbash, M., Hussainey, K., \& Ibrahim, A. (2016). The determinants of voluntary disclosure in Saudi Arabia: an empirical study. International Journal of Accounting, Auditing and Performance Evaluation, 12(3), 213-236.

Haddad, A. E., Sbeiti, W. M., \& Qasim, A. (2017). Accounting legislation, corporate governance codes and disclosure in Jordan: a review. International Journal of Law and Management, 59(1), 147-176.

Haley, U. C. (1991). Corporate contributions as managerial masques: Reframing corporate contributions as strategies to influence society. Journal of Management studies, 28(5), 485-510.

Henderson, M. T., \& Malani, A. (2009). Corporate philanthropy and the market for altruism. Colum. L. Rev., 109, 571.

Hillman, A. J., \& Keim, G. D. (2001). Shareholder value, stakeholder management, and social issues: what's the bottom line? Strategic Management Journal, 22(2), 125139.

Houqe, M. N., van Zijl, T., Karim, A. W., \& St George, T. (2019). The value relevance of corporate donations. Pacific-Basin Finance Journal.

Huber, P. J. (1967). The behavior of maximum likelihood estimates under nonstandard conditions. Paper presented at the Proceedings of the fifth Berkeley symposium on mathematical statistics and probability.

Ibrahim, A., Habbash, M., \& Hussainey, K. (2019). Corporate governance and risk disclosure: evidence from Saudi Arabia. International Journal of Accounting, Auditing and Performance Evaluation, 15(1), 89-111.

Ibrahim , A. H., \& Hanefah , M. M. (2016). Board diversity and corporate social responsibility in Jordan. Journal of Financial Reporting and Accounting, 14(2), 279-298. 
Jensen, M. C. (2002). Value maximization, stakeholder theory, and the corporate objective function. Business ethics quarterly, 235-256.

Jia, M., Xiang, Y., \& Zhang, Z. (2019). Indirect reciprocity and corporate philanthropic giving: how visiting officials influence investment in privately owned Chinese firms. Journal of Management Studies, 56(2), 372-407.

Karyawati, P. G., Angesty, K., \& Joshi, P. L. (2017). A study of inverted U-shape relationship between firm size and corporate social responsibility-the case of Indonesia. International Journal of Accounting, Auditing and Performance Evaluation, 13(3), 308-323.

Lee, D. D., Faff, R. W., \& Langfield-Smith, K. (2009). Revisiting the vexing question: does superior corporate social performance lead to improved financial performance? Australian Journal of Management, 34(1), 21-49.

Li, S., Song, X., \& Wu, H. (2015). Political connection, ownership structure, and corporate philanthropy in China: A strategic-political perspective. Journal of Business Ethics, 129(2), 399-411.

Li, X., Li, C., Wang, Z., Jiao, W., \& Pang, Y. (2020). The effect of corporate philanthropy on corporate performance of Chinese family firms: The moderating role of religious atmosphere. Emerging Markets Review, 100757.

Lin, T.-L., Liu, H.-Y., Huang, C.-J., \& Chen, Y.-C. (2018). Ownership structure, board gender diversity and charitable donation. Corporate Governance: The International Journal of Business in Society.

Liu, W., Wei, Q., Huang, S.-Q., \& Tsai, S.-B. (2017). Doing good again? A multilevel institutional perspective on corporate environmental responsibility and philanthropic strategy. International journal of environmental research and public health, 14(10), 1283.

Majumdar, S. K. (1997). The impact of size and age on firm-level performance: some evidence from India. Review of industrial organization, 12(2), 231-241.

Masulis, R. W., \& Reza, S. W. (2014). Agency problems of corporate philanthropy. The Review of Financial Studies, 28(2), 592-636.

Mescon, T. S., \& Tilson, D. J. (1987). Corporate philanthropy: A strategic approach to the bottom-line. California Management Review, 29(2), 49-61.

Mullen, J. (1997). Performance-based corporate philanthropy: How" giving smart" can further corporate goals. Public Relations Quarterly, 42(2), 42.

Navarro, P. (1988). Why do corporations give to charity? Journal of business, 61(1), 65.

Orlitzky, M., Schmidt, F. L., \& Rynes, S. L. (2003). Corporate social and financial performance: A meta-analysis. Organization studies, 24(3), 403-441.

Orlitzky, M., Siegel, D. S., \& Waldman, D. A. (2011). Strategic corporate social responsibility and environmental sustainability. Business \& Society, 50(1), 6-27. 
Owusu, A., \& Weir, C. (2018). Agency costs, ownership structure and corporate governance mechanisms in Ghana. International Journal of Accounting, Auditing and Performance Evaluation, 14(1), 63-84.

Patten, D. M. (2002). Media exposure, public policy pressure, and environmental disclosure: An examination of the impact of tri data availability.

Patten, D. M. (2008). Does the market value corporate philanthropy? Evidence from the response to the 2004 tsunami relief effort. Journal of Business Ethics, 81(3), 599607.

Pichler, S., Cordazzo, M., \& Rossi, P. (2018). An analysis of the firms-specific determinants influencing the voluntary IFRS adoption: evidence from Italian private firms. International Journal of Accounting, Auditing and Performance Evaluation, 14(1), 85-104.

Pratten, J. D., \& Abdulhamid Mashat, A. (2009). Corporate social disclosure in Libya. Social Responsibility Journal, 5(3), 311-327.

Rehman, A., \& Jun, J. C. (2020). Does Corporate Giving Matter in Firm Performance? Asian Journal of Economics, Finance and Management, 126-130.

Reverte, C. (2009). Determinants of corporate social responsibility disclosure ratings by Spanish listed firms. Journal of Business Ethics, 88(2), 351-366.

Roberts, R. W. (1992). Determinants of corporate social responsibility disclosure: An application of stakeholder theory. Accounting, organizations and society, 17(6), 595-612.

Saeidi, S. P., Sofian, S., Saeidi, P., Saeidi, S. P., \& Saaeidi, S. A. (2015). How does corporate social responsibility contribute to firm financial performance? The mediating role of competitive advantage, reputation, and customer satisfaction. Journal of Business Research, 68(2), 341-350. doi:https://doi.org/10.1016/j.jbusres.2014.06.024

Saiia, D. H. (2001). Philanthropy and corporate citizenship: Strategic philanthropy is good corporate citizenship. Journal of Corporate Citizenship(2), 57-74.

Schmidt, M. A., \& Cracau, D. (2017). A Cross-Country Comparison of the Corporate Social Responsibility Orientation in Germany and Qatar: An Empirical Study among Business Students. Business and Professional Ethics Journal.

Seifert, B., Morris, S. A., \& Bartkus, B. R. (2003). Comparing big givers and small givers: Financial correlates of corporate philanthropy. Journal of Business Ethics, 45(3), 195-211.

Seifert, B., Morris, S. A., \& Bartkus, B. R. (2004). Having, giving, and getting: Slack resources, corporate philanthropy, and firm financial performance. Business \& society, 43(2), 135-161.

Sharabati, A.-A. A. (2018). Effect of corporate social responsibility on Jordan pharmaceutical industry's business performance. Social Responsibility Journal, 14(3), 566-583. 
Simon, F. L. (1992). Marketing green products in the triad. Columbia Journal of World Business, 27(3-4), 268-285.

Tilt, C. A. (2016). Corporate social responsibility research: the importance of context. International journal of corporate social responsibility, 1(1), 2.

Wang, H., Choi, J., \& Li, J. (2008). Too little or too much? Untangling the relationship between corporate philanthropy and firm financial performance. Organization Science, 19(1), 143-159.

Wang, H., \& Qian, C. (2011). Corporate philanthropy and corporate financial performance: The roles of stakeholder response and political access. Academy of Management journal, 54(6), 1159-1181.

Wang, J., \& Coffey, B. S. (1992). Board composition and corporate philanthropy. Journal of Business Ethics, 11(10), 771-778.

Weber, M. (2008). The business case for corporate social responsibility: A companylevel measurement approach for CSR. European Management Journal, 26(4), 247-261.

White, H. (1982). Maximum likelihood estimation of misspecified models. Econometrica: Journal of the econometric society, 1-25.

Williams, R. J. (2003). Women on Corporate Boards of Directors and their Influence on Corporate Philanthropy. Journal of Business Ethics, 42(1), 1-10. Retrieved from http://ezproxy.uws.edu.au/login?url=http://search.ebscohost.com/login.aspx?direc $\mathrm{t}=$ true \&db=heh\&AN=9198181\&site=ehost-live \&scope $=$ site

Wooldridge, J. M. (2013). Introductory econometrics : a modern approach (5th ed. ed.). Mason, Ohio: Mason, Ohio : South-Western Cengage Learning.

Zhang, R., Rezaee, Z., \& Zhu, J. (2010). Corporate philanthropic disaster response and ownership type: Evidence from Chinese firms' response to the Sichuan earthquake. Journal of Business Ethics, 91(1), 51. 
Tables

Table I: Definition of the study variables

\begin{tabular}{|c|c|c|}
\hline Variables & Description & Data sources \\
\hline \multicolumn{3}{|c|}{ Dependent variables } \\
\hline DONTS & The ratio of corporate donations to company total assets & Annual reposts \\
\hline \multicolumn{3}{|c|}{ Independent variables } \\
\hline SIZE & The natural logarithm of total assets & Annual reposts \\
\hline AGE & $\begin{array}{l}\text { The natural logarithm of the number of years since the initial } \\
\text { public offering }\end{array}$ & $\begin{array}{l}\text { Amman stock exchange } \\
\text { websitevi }\end{array}$ \\
\hline PROF & Return on investment & SDC \\
\hline LEVER & Debit ratio & SDC \\
\hline MEDIA & $\begin{array}{l}\text { The average number of related articles published by two Jordanian } \\
\text { newspapers }\end{array}$ & $\begin{array}{l}\text { "Addustour" } \\
\text { Newspaper and "Alrai" } \\
\text { Newspaper.vii }\end{array}$ \\
\hline OWNC & $\begin{array}{l}\text { The ratio of shares held by the substantial shareholders (above } 5 \\
\% \text { ) }\end{array}$ & Annual report \\
\hline FOWN & Ratio of shares held by family members and their relatives & Annual report \\
\hline GOWN & The ratio of shares held by government institutions & Annual report \\
\hline
\end{tabular}

This table presents the measurements of the study variables

Notes: (DONTS) is the corporate donations, (SIZE) is the company size, (AGE) is the company age, (PROF) is the company profitability, (LEVER) is the company financial leverage, (MEDIA) is to what extent the company has exposed to social and environmental issues, (OWNC) is the ownership concentration, (GOWN) is the government ownership, (FOWN) is the family ownership 
Table II: Descriptive Statistics

\begin{tabular}{lllll}
\hline Variables & Mean & Std.Dev. & Min & Max \\
\hline DONTS & .528 & 1.189 & 0 & 9.985 \\
SIZE & 10.287 & 1.394 & 5.979 & 14.394 \\
AGE & 2.953 & .738 & 0 & 4.357 \\
PROF & 2.013 & 12.612 & -195.296 & 38.397 \\
LEVER & .325 & .218 & 0 & 1.042 \\
MEDIA & .584 & 1.522 & 0 & 15 \\
OWNC & .605 & .235 & 0 & .999 \\
FOWN & .195 & .246 & 0 & .956 \\
GOWN & .057 & .152 & 0 & .999 \\
\hline
\end{tabular}

This table presents the descriptive statistics of corporate donations, in addition to explanatory variables

Notes: (DONTS) is the corporate donations, (SIZE) is the company size, (AGE) is the company age, (PROF) is the company profitability, (LEVER) is the company financial leverage, (MEDIA) is to what extent the company has exposed to social and environmental issues, (OWNC) is the ownership concentration, (GOWN) is the government ownership, (FOWN) is the family ownership 
Table III: Matrix of correlations

\begin{tabular}{|c|c|c|c|c|c|c|c|c|c|}
\hline Variables & (1) & (2) & (3) & (4) & (5) & (6) & (7) & (8) & (9) \\
\hline DONTS & 1.000 & & & & & & & & \\
\hline SIZE & 0.288 & 1.000 & & & & & & & \\
\hline AGE & 0.109 & 0.093 & 1.000 & & & & & & \\
\hline PROF & 0.284 & 0.227 & 0.118 & 1.000 & & & & & \\
\hline LEVER & -0.133 & 0.253 & 0.177 & -0.185 & 1.000 & & & & \\
\hline MEDIA & 0.271 & 0.435 & 0.155 & 0.159 & 0.049 & 1.000 & & & \\
\hline OWNC & 0.155 & 0.080 & 0.048 & 0.127 & -0.139 & 0.072 & 1.000 & & \\
\hline FOWN & -0.052 & -0.056 & -0.090 & 0.103 & -0.167 & -0.013 & -0.169 & 1.000 & \\
\hline GOWN & 0.215 & 0.305 & 0.168 & 0.114 & -0.001 & 0.258 & 0.237 & -0.137 & 1.000 \\
\hline
\end{tabular}

This table reports the Pearson correlation matrix between the study variables

Notes: (DONTS) is the corporate donations, (SIZE) is the company size, (AGE) is the company age, (PROF) is the company profitability, (LEVER) is the company financial leverage, (MEDIA) is to what extent the company has exposed to social and environmental issues, $(\mathrm{OWNC})$ is the ownership concentration, $(G O W N)$ is the government ownership, (FOWN) is the family ownership 
Table IV: Study results

\begin{tabular}{|c|c|c|c|}
\hline VARIABLES & Model (1) & Model (2) & Model (3) \\
\hline \multirow[t]{2}{*}{ DONTS $_{t-1}$} & & $0.541 * * *$ & \\
\hline & & [5.24] & \\
\hline \multirow[t]{2}{*}{ SIZE } & $0.103 * * *$ & $0.0520 * *$ & $0.178 * * *$ \\
\hline & [3.64] & [2.33] & {$[4.50]$} \\
\hline \multirow[t]{2}{*}{ AGE } & $0.119 * *$ & $0.117 *$ & $0.103^{*}$ \\
\hline & [2.29] & [1.94] & [1.87] \\
\hline \multirow[t]{2}{*}{ PROF } & $0.0175^{* *}$ & $0.0101 *$ & $0.00935^{* * *}$ \\
\hline & [2.31] & {$[1.77]$} & {$[3.27]$} \\
\hline \multirow[t]{2}{*}{ LEVER } & $-0.574 * * *$ & $-0.307 *$ & $-0.713 * * *$ \\
\hline & {$[-2.76]$} & {$[-1.75]$} & {$[-4.20]$} \\
\hline \multirow[t]{2}{*}{ MEDIA } & $0.162 * *$ & 0.0832 & 0.0812 \\
\hline & {$[2.00]$} & {$[1.21]$} & [1.52] \\
\hline \multirow[t]{2}{*}{ OWNC } & 0.205 & 0.0659 & 0.129 \\
\hline & {$[1.25]$} & {$[0.50]$} & {$[0.86]$} \\
\hline \multirow[t]{2}{*}{ FOWN } & $-0.523 * * *$ & $-0.332 * *$ & $-0.278 * *$ \\
\hline & {$[-3.47]$} & {$[-2.26]$} & {$[-2.12]$} \\
\hline \multirow[t]{2}{*}{ GOWN } & $0.853 * * *$ & $0.442 *$ & $0.203^{*}$ \\
\hline & [2.62] & {$[1.73]$} & [1.77] \\
\hline \multirow[t]{2}{*}{ Constant } & $-0.524 * *$ & -0.354 & $-2.808 * * *$ \\
\hline & {$[-2.29]$} & {$[-1.54]$} & {$[-3.77]$} \\
\hline Observations & 601 & 513 & 601 \\
\hline R-squared & 0.304 & 0.539 & 0.273 \\
\hline
\end{tabular}

Robust t-statistics in parentheses, *** $\mathrm{p}<0.01, * * \mathrm{p}<0.05, * \mathrm{p}<0.1$

This table reports the OLS Regression Results of the relationship between corporate donations and firm characteristics and ownership structure of the Jordanian companies

Notes: (DONTS) is the corporate donations, (SIZE) is the company size, (AGE) is the company age, (PROF) is the company profitability, (LEVER) is the company financial leverage, (MEDIA) is to what 
extent the company has exposed to social and environmental issues, $(O W N C)$ is the ownership

concentration, $(G O W N)$ is the government ownership, (FOWN) is the family ownership

\section{Notes}

${ }^{\mathrm{i}}$ ADMICAL is a network of members and key organizations composed mostly of companies and foundations having philanthropic actions as well as charities. http://admical.org/

${ }^{\mathrm{ii}} \mathrm{CECP}$ is the only international forum of business leaders focused exclusively on raising the level and quality of corporate philanthropy.

iii The Chronicle of Philanthropy is a magazine based in Washington, DC, which covers not-for-profit business.

iv https://www.jsc.gov.jo

${ }^{v}$ https://www.istd.gov.jo

vi Amman stock exchange website: https://www.ase.com.jo/en

vii “Addustour” Newspaper website: https://www.addustour.com / Alrai” Newspaper: http://alrai.com/ 